Katarzyna DANiel

Uniwersytet Opolski

\title{
PRAWO PETYCJI W TEORII I PRAKTYCE SEJMU VIII KADENCJI
}

\section{WPROWADZENIE}

Słowo „petycja” wywodzi się od łacińskiego petitio, które oznacza prośbę, żądanie, skargę ${ }^{1}$. Prawo petycji uznawane jest za najłatwiejsze, najbardziej powszechne i dostępne, w porównaniu z pozostałymi formami dochodzenia przez podmioty przynależnych im praw, wolności oraz ochrony interesów. Stanowi także jedno z najstarszych praw jednostki żyjącej w państwie demokratycznym. Prawo petycji daje również obywatelom jedną z wielu możliwości partycypacji w życiu publicznym czy choćby kontroli działania organów władzy publicznej².

Konstytucjonaliści wskazują na ścisły związek prawa petycji z demokratycznym państwem prawnym. Halina Zięba-Załucka uważa, że „petycje to pole do nowych działań w imię interesów społecznych i rozwoju demokracji”3. Z kolei Bogusław Banaszak wskazuje, że

\footnotetext{
1 S. Grabowska, P. Kapusta, Pojęcie i charakter prawa petycji, [w:] Teoretyczne i praktyczne aspekty realizacji prawa petycji, red. R. BALICKI, M. JABŁOŃsKI, Wrocław 2015, s. 37.

2 K. Grabarczy K, Prawo petycji w Rzeczypospolitej Polskiej oraz w Republice Litewskiej, «Kortowski Przegląd Prawniczy» 1/2016, s. 32.

3 H. ZięBa-Zaєucka, Prawo petycji w Rzeczypospolitej Polskiej, «Przegląd Prawa Konstytucyjnego»1/2010, s. 21.
} 
w państwach demokratycznych petycja utożsamiana jest ze środkiem, za pomocą którego grupa osób lub jednostka zwraca się do organu władzy publicznej z propozycją zmian, reform bądź krytyką pewnych rozwiązań ${ }^{4}$. Również Ryszard Piotrowski sądzi, że prawo petycji jest niezbędnym elementem spójnym z zasadą demokratycznego państwa prawnego oraz dialogu społecznego, stanowiącym podstawy praw w państwie ${ }^{5}$. Anna Rytel-Warzocha pisze, że prawo petycji „przyczynia się do rozwoju społeczeństwa obywatelskiego poprzez uspołecznienie procesu decyzyjnego, służy ochronie praw i wolności jednostki”6.

Prawo petycji jako pierwsza wprowadziła Konstytucja marcowa z 1921 r., stanowiąc, że „obywatele mają prawo wnosić pojedynczo lub zbiorowo petycje do wszelkich ciał reprezentacyjnych i władz publicznych, państwowych i samorządowych"7. Obecnie prawo do składania petycji zagwarantowane jest w rozdziale II ustawy zasadniczej - „Wolności, prawa i obowiązki człowieka i obywatela”. Z kolei umieszczenie prawa petycji w części „Wolności i prawa polityczne” świadczy o umieszczeniu go w kategorii praw politycznych ${ }^{8}$. Artykuł 63 Konstytucji stanowi bowiem, że: „Każdy ma prawo składać petycje, wnioski i skargi w interesie publicznym, własnym lub innej osoby za jej zgodą do organów władzy publicznej oraz do organizacji i instytucji społecznych w związku z wykonywanymi przez nie zadaniami zleconymi z zakresu

4 B. Banaszak, Konstytucja Rzeczypospolitej Polskiej. Komentarz, Warszawa 2009, s. 323.

5 R. Ріотrowsкi, Konstytucyjne uwarunkowania prawa petycji oraz pożadanych kierunków zmian legislacyjnych w tym zakresie, [w:] Prawo petycji w ustawodawstwie polskim, red. J. Tracz-Dral, Warszawa 2008, s. 24-25.

6 A. Rytel-Warzocha, Instytucja petycji w Polsce oraz w krajach europejskich stan obecny i perspektywy, [w:] Instytucja petycji w Polsce oraz w innych krajach europejskich - stan obecny i perspektywy, red. R. STAWICKI, Warszawa 2015, s. 3.

7 Art. 107 ustawy z 17 marca 1921 r. Konstytucja Rzeczypospolitej Polskiej (Dz. U. Nr 44, poz. 267).

8 K. DziaŁocha, Prawo petycji w obowiąującym ustawodawstwie i proponowane kierunki zmian, [w:] Prawo petycji w ustawodawstwie polskim..., s. 1. 
administracji publicznej. Tryb rozpatrywania petycji, wniosków i skarg określa ustawa"9.

W literaturze przedmiotu pojawiały się jednak głosy, że uregulowanie trybu rozpatrywania petycji nie wymaga uchwalania odrębnej ustawy, gdyż wystarczą jedynie zmiany w kodeksie postępowania administracyjnego $^{10}$. Senat w 2008 r. postanowił wyjść naprzeciw od dawna postulowanym przez organizacje pozarządowe zmianom i zmienił swój regulamin w sposób umożliwiający obywatelom korzystanie z prawa petycji. Obowiązek rozpatrywania petycji powierzono senackiej Komisji Praw Człowieka i Praworządności ${ }^{11}$.

Konstytucja gwarantowała prawo składania petycji już od 1997 r., jednak dopiero w 2015 r. stosowna ustawa regulująca tryb rozpatrywania petycji weszła w życie. Do czasu przyjęcia ustawy o petycjach wszelkie petycje rozpatrywane były na podstawie art. 221 k.p.a., choć dalsze przepisy tejże ustawy regulowały jedynie tryb rozpatrywania skarg i wniosków. Ponadto przepisy kodeksu postępowania administracyjnego nie miały zastosowania do petycji składanych do Sejmu lub Senatu ${ }^{12}$. Anna Rytel-Warzocha uważa, że „brak regulacji ustawowej przez tak długi czas niewątpliwie stanowi jedno z największych zaniechań legislacyjnych"13.

\section{UstaWA O PETYCJACH}

Ustawa o petycjach w zdecydowanej większości oparta jest na projekcie z 9 stycznia 2013 r. Senatorów Rzeczypospolitej Polskiej, którzy skorzystali z prawa inicjatywy ustawodawczej ${ }^{14}$. Cały proces legislacyjny (od dnia wystąpienia $\mathrm{z}$ inicjatywą ustawodawczą senatorów) do

\footnotetext{
9 Art. 63 Konstytucji Rzeczypospolitej Polskiej z 2 kwietnia 1997 r. (Dz. U. z Nr 78, poz. 483 ze zm. i sprost.).

10 W. OrŁowski, Konstytucyjne uwarunkowania prawa petycji, [w:] Prawo petycji w ustawodawstwie polskim..., s. 16.

11 H. ZięBA-ZaŁUCKa, op. cit., s. 9.

12 K. Grabarczy K, op. cit., s. 34.

13 A. Rytel-Warzocha, op. cit., s. 3.

14 Projekt ustawy o petycjach z 9 stycznia 2013 r., druk senacki nr 285.
} 
dnia podpisania przez głowę państwa obejmował okres półtora roku. Senatorowie uznali okres sześciu miesięcy na wejście w życie ustawy za wystarczający do przygotowania się organów rozpatrujących, jednak ustawodawca okres ten wydłużył do 12 miesięcy od dnia jej ogłoszenia ${ }^{15}$.

Pierwotnym założeniem celu składania petycji było skłonienie adresata do podjęcia określonego działania, zajęcia danego stanowiska czy zaniechania działania już podjętego. Tego typu regulacja nie znalazła się w obecnie obowiązującej ustawie ${ }^{16}$. Petycja stanowi tzw. miękki instrument, ponieważ jej złożenie nie ma bezpośrednio wpływu na decyzję organu władzy publicznej ani nie prowadzi do rozstrzygnięć ze skutkiem prawnym ${ }^{17}$.

\subsection{Podmiot wnoszący petycję}

Podmiotem wnoszącym petycję może być osoba fizyczna, osoba prawna, jednostka organizacyjna niebędąca osobą prawną bądź grupa wskazanych podmiotów ${ }^{18}$. Instytucja petycji nie jest więc powiązana z obywatelstwem, ponieważ przysługuje każdemu, niezależnie od przynależności państwowej ${ }^{19}$. Niemożliwe jest zatem stworzenie zamkniętego katalogu podmiotów uprawnionych do złożenia petycji, bo Konstytucja Rzeczypospolitej Polskiej wprost przyznaje to prawo „każdemu”20.

15 Art. 21 projektu ustawy o petycjach w zw. z art. 17 ustawy z 11 lipca 2014 r. o petycjach (Dz. U. z 2018 r. poz. 870).

16 Art. 2 ust. 4 projektu ustawy o petycjach.

17 E. WójcickA, Ustawa z dnia 11 lipca 2014 r. o petycjach - uwagi krytyczne, «RPEiS» 78.1/2017, s. 162.

18 Pierwotnie projekt zakładał wyłączenie z grupy wnioskodawców podmiotów wykonujących zawodową działalność lobbingową w sprawie projektu aktu normatywnego, który jest przedmiotem prac Rady Ministrów, Sejmu, Senatu lub jest ujęty i ogłoszony w programie prac legislacyjnych Rady Ministrów, jeśli prowadzą one działalność lobbingową dotyczącą tegoż projektu na rzecz osób trzecich. Propozycja nie została jednak zachowana w obecnie obowiązującej ustawie o petycjach. Art. 5 projektu ustawy o petycjach.

19 E. WójCICKA, Przywrócenie instytucji petycji w polskim porządku prawnym, «PEiS» 68.4/2006, s. 38 .

20 E. WóJCICKA, op. cit., s. 164. 
Ustawa zasadnicza nie ogranicza w żaden sposób ilościowo wnoszonych petycji, zatem nie ma mowy o nadużyciu tego uprawnienia ${ }^{21}$.

Petycję składa się do organu władzy publicznej, instytucji lub organizacji społecznej, która wykonuje zadania zlecone z zakresu administracji publicznej ${ }^{22}$. Petycję można składać w interesie podmiotu, który ją wnosi, publicznym, a także podmiotu trzeciego (za jego zgodą) ${ }^{23}$.

\subsection{Przedmiot petycji}

Przedmiot petycji może stanowić zmiana przepisów prawa, podjęcie rozstrzygnięcia bądź innego działania w sprawie związanej z podmiotem wnoszącym petycję, a dotyczącym życia zbiorowego albo wartości, które wymagają szczególnej ochrony w imię dobra wspólnego i mieszczą się w zakresie zadań oraz kompetencji adresata ${ }^{24}$. Ustawa nie ogranicza liczby spraw objętych petycją, zatem może ona dotyczyć jednej lub więcej spraw ${ }^{25}$.

Zamysłem projektodawcy było skonkretyzowanie i dookreślenie prawa petycji, co jednak nie nastąpiło. Obecnie obowiązująca ustawa o petycjach nie definiuje w sposób wyraźny oraz jednoznaczny pojęcia petycji, a także nie odróżnia jej od skarg i wniosków ${ }^{26}$. Ta ogólnikowość sformułowań nie stwarza możliwości do pewnego i bezdyskusyjnego odróżnienia petycji od wniosków i skarg. Zatem to uznaniowość organu decydować będzie, czy żądanie podmiotu zakwalifikować jako skargę, wniosek lub petycję. Trudności interpretacyjne występują również po stronie organów rozpatrujących petycję, przez co zachodzi ryzyko rozbieżności oraz błędnej praktyki stosowania prawa ${ }^{27}$.

21 Z. Gromeк, Realizacja prawa petycji przez Sejm VIII kadencji (lata 2015-2018). Wybrane zagadnienia, «Przegląd Sejmowy» 3.(152)/2019, s. 23-24.

22 Art. 2 ust. 1 ustawy o petycjach.

23 Art. 2 ust. 2 ustawy o petycjach.

24 Art. 2 ust. 3 ustawy o petycjach.

25 Z. GromeK, op. cit., s. 26.

26 E. WóJCICKA, op. cit., s. 161.

27 Ibidem, s. 164. 
To treść żądania, nie jego forma zewnętrzna, decyduje o tym, czy pismo jest petycją ${ }^{28}$. Wojciech Sokolewicz wskazuje, że szerokie ujęcie prawa petycji pełni niejako funkcję gwarancyjną dla pozostałych praw oraz wolności o charakterze politycznym, bowiem gdy wszystkie inne środki ochrony zawiodą, w każdej chwili można skorzystać z prawa do składania petycji lub skargi ${ }^{29}$.

Prawo petycji stanowi publiczne prawo podmiotowe o charakterze roszczeniowym ${ }^{30}$. Uprawnienie to gwarantuje podmiotowi wnoszącemu petycję niemożność zastosowania wobec niego negatywnych konsekwencji, chyba że treść petycji będzie posiadała znamiona przestępstwa. Po stronie adresatów petycji powstaje natomiast obowiązek zajęcia stanowiska oraz udzielenia odpowiedzi podmiotowi składającemu petycję $^{31}$. Istnieją dwie formy złożenia petycji - fakultatywnie do wyboru dla wnioskodawcy - pisemna lub za pomocą środków komunikacji elektronicznej ${ }^{32}$.

\subsection{Elementy petycji}

Ustawa o petycjach wskazuje jedynie cztery elementy, jakie powinna ona zawierać. Obowiązkowe jest oznaczenie podmiotu wnoszącego petycję (w przypadku gdy jest to grupa podmiotów, należy wskazać oznaczenie każdego z nich i osobę reprezentującą podmiot wnoszący petycję). Ponadto obligatoryjne jest wskazanie siedziby podmiotu wnoszącego petycję lub miejsca zamieszkania oraz adresu do korespondencji (w przypadku gdy jest to grupa podmiotów, należy wskazać siedzibę lub miejsce zamieszkania każdego z tych podmiotów) ${ }^{33}$. Bez oznaczenia wskazanych wyżej elementów, petycję pozostawia się bez rozpatrzenia ${ }^{34}$.

28 Art. 3 ustawy o petycjach.

29 W. Sokolewicz, Uwagi do art. 63, [w:] Konstytucja Rzeczypospolitej Polskiej. Komentarz, red. L. GARLICKI, Warszawa 2005, s. 4.

30 M. Masternak-Kubiak, P. Kuczma, Prawo petycji jako publiczne prawo podmiotowe (aspekt podmiotowy i przedmiotowy), [w:] Teoretyczne i praktyczne aspekty realizacji prawa petycji..., s. 265.

31 Projekt ustawy o petycjach, s. 2.

32 Art. 4 ust. 1 ustawy o petycjach.

33 Art. 4 ust. 2 ustawy o petycjach.

34 Art. 7 ust. 1 ustawy o petycjach. 
Są to zatem jej elementy obligatoryjne, bez których nie można nadać dalszego biegu petycji. Kolejnym elementem petycji jest wskazanie przedmiotu petycji i oznaczenie jej adresata ${ }^{35}$, a w przypadku podmiotu trzeciego jego oznaczenie oraz wyrażenie zgody na występowanie w jego interesie. Są to elementy petycji, których brak można uzupełnić lub wyjaśnić w terminie 14 dni od wezwania przez organ rozpatrujący, pod rygorem pozostawienia petycji bez rozpatrzenia ${ }^{36}$.

Petycja zostaje przekazana niezwłocznie (nie później niż w terminie 30 dni od złożenia) pozostałym właściwym do rozpatrzenia podmiotom, o czym zawiadamia się równocześnie podmiot wnoszący petycję ${ }^{37}$.

\subsection{Rozpatrzenie petycji}

Petycje składane do organów stanowiących jednostki samorządu terytorialnego rozpatrywane są przez te organy. Z kolei w przypadku petycji składanych do Sejmu lub Senatu, rozpatrywane są one przez te organy, jeśli w ich regulaminach nie wskazano innego wewnętrznego organu właściwego w tym zakresie ${ }^{38}$.

Organ powinien rozpatrzyć petycję niezwłocznie, lecz nie później niż w terminie trzech miesięcy od dnia jej złożenia. Termin ten liczy się odpowiednio od dnia uzupełnienia braków formalnych przez podmiot wnoszący petycję lub przekazania organowi właściwemu do rozpatrzenia w przypadku niewłaściwego zaadresowania petycji ${ }^{39}$. W przypadku zaistnienia okoliczności uniemożliwiających rozpatrzenie petycji w terminie, a niezależnych od podmiotu rozpatrującego petycję, termin na jej rozpatrzenie przedłuża się, lecz o nie dłużej niż trzy miesiące od daty upływu pierwszego terminu ${ }^{40}$.

\footnotetext{
35 Art. 4 ust. 2 ustawy o petycjach.

36 Art. 7 ust. 2 ustawy o petycjach.

37 Art. 6 ust. 2 ustawy o petycjach.

38 Art. 9 ust. 1-2 ustawy o petycjach.

39 Art. 10 ust. 1-2 ustawy o petycjach.

40 Art. 10 ust. 3 ustawy o petycjach.
} 
Podmiot właściwy do rozpatrzenia petycji może zarządzić łączne rozpatrywanie petycji (tzw. petycję wielokrotną) ${ }^{41}$. Jest to możliwe jedynie wówczas, gdy w terminie miesiąca od otrzymania przez podmiot rozpatrujący petycję, składane są kolejne petycje dotyczące tej samej sprawy. Okres oczekiwania na dalsze petycje nie może być dłuższy niż dwa miesiące, liczone od dnia ogłoszenia na stronie internetowej przez podmiot rozpatrujący ${ }^{42}$.

Podmiot rozpatrujący petycje jest zobowiązany do poinformowania podmiotu wnoszącego petycję o sposobie jej załatwienia wraz z uzasadnieniem, przy czym forma jest fakultatywna (pisemna lub za pomocą środków komunikacji elektronicznej). Na sposób załatwienia petycji nie przysługuje żaden środek odwoławczy ${ }^{43}$.

\section{ROZPATRYWANIE PETYCJI ZŁOŻONYCH DO SEJMU}

Postępowanie w sprawach petycji zostało ujęte w rozdziale 9a regulaminu Sejmu. Postępowanie rozpoczyna skierowanie petycji przez Marszałka Sejmu do Komisji do spraw Petycji celem jej rozpatrzenia. W przypadku, gdy petycja nie spełnia wymogów formalnych, Marszałek Sejmu pozostawia ją bez rozpoznania bądź wzywa podmiot wnoszący petycję do jej uzupełnienia lub wyjaśnienia treści. Marszałek Sejmu ma możliwość zarządzenia łącznego rozpatrywania petycji. Termin rozpatrzenia petycji jest wyznaczany przez Marszałka Sejmu, lecz zgodnie $\mathrm{z}$ terminami wskazanymi w ustawie o petycjach ${ }^{44}$.

Rozpatrzenie petycji rozpoczyna przedstawienie petycji przez posła wskazanego przez prezydium Komisji do spraw Petycji. Następnie

\footnotetext{
41 Celem wprowadzenia tego przepisu było zapobieganie wielokrotnemu rozpatrywaniu tych samych spraw, w wyniku wnoszenia kolejnych petycji, które nie zawierają żadnych nowych treści, czy ponawiane są z niewiedzy podmiotu wnoszącego lub pobudek pieniackich. Projekt ustawy o petycjach, s. 6.

42 Art. 11 ust. 1-3 ustawy o petycjach.

43 Art. 13 ust. 1-2 ustawy o petycjach.

44 Art. 126b \$ 1-4 uchwały Sejmu Rzeczypospolitej Polskiej z 30 lipca 1992 r. Regulamin Sejmu Rzeczypospolitej Polskiej (M.P. z 2020 r., poz. 476).
} 
odbywa się dyskusja i rozstrzygnięcie o sposobie załatwienia petycji. Komisja ma możliwość zwrócenia się do innych komisji sejmowych o wyrażenie ich opinii na temat rozpatrywanej petycji ${ }^{45}$.

Istnieje kilka możliwości załatwienia petycji:

- nieuwzględnienie przez Komisję żądania będącego przedmiotem petycji;

- wniesienie przez Komisję projektu ustawy/uchwały;

- przedstawienie przez Komisję innej komisji sejmowej opinii w sprawie rozpatrywanego przez nią projektu uchwały/ustawy;

- wniesienie przez przedstawiciela Komisji poprawki bądź wniosku do projektu ustawy/uchwały w czasie jego rozpatrywania przez inną komisję sejmową albow czasie jego drugiego czytania;

- wystąpienie przez Komisję z wnioskiem o przeprowadzenie kontroli przez Najwyższą Izbę Kontroli ${ }^{46}$.

Komisja jest zobowiązana do przekazania Marszałkowi Sejmu informacji o sposobie załatwienia petycji lub o pozostawieniu petycji bez rozpatrzenia (z uwagi na przedmiot petycji, który był już rozpatrywany, a podmiot wnoszący petycję nie powołał się na nowe fakty i okoliczności) wraz z uzasadnieniem ${ }^{47}$.

Następnie Marszałek Sejmu zawiadamia podmiot, który wniósł petycję, o sposobie jej załatwienia, natomiast w przypadku pozostawienia petycji bez rozpoznania, o jakiej mowa wyżej, przekazuje informację o poprzednim sposobie załatwienia petycji wraz z uzasadnieniem ${ }^{48}$. Jeśli postępowanie w sprawie petycji nie zostało zakończone przed upływem kadencji Sejmu, wówczas jest ono kontynuowane przez Komisję w następnej kadencji Sejmu ${ }^{49}$.

\footnotetext{
45 Art. $126 c \$ 1-2$ regulaminu Sejmu.

46 Art. $126 \mathrm{c} \$ 3-4$, art. $126 \mathrm{c} \$ 3 \mathrm{w}$ zw. $\mathrm{z}$ art. 162a ust. 1 regulaminu Sejmu.

47 Art. 126d w zw. z art. 12 ust. 1 ustawy o petycjach.

48 Art. 126e regulaminu Sejmu.

49 Art. 126e, art. 126g regulaminu Sejmu.
} 
4. Praktyka Rozpatry Wania Petycji PRZEZ SEJM ViII KadenCJI

W trakcie VIII kadencji Sejmu złożono 15 petycji wielokrotnych, przy czym 13 zostało złożonych przez osoby fizyczne, 1 przez fundacje i stowarzyszenia, natomiast co do 1 petycji dane wnioskodawcy nie zostały opublikowane. Co ciekawe, aż 12 petycji wielokrotnych rozpatrzono poprzez uchwalenie dezyderatu, w przypadku 1 petycji wystąpiono o opinię do komisji, a także nie uwzględniono żądania będącego przedmiotem 1 petycji, natomiast 1 petycję rozpatrzono w sposób inny. Biorąc pod uwagę podmiot wnoszący petycję, aż 80,2\% wnioskodawców stanowiły osoby fizyczne, a następnie stowarzyszenia - 9,1\%. Wśród innych podmiotów wnoszących petycję wskazuje się między innymi na: radę seniorów, radę miasta, inspektorat ochrony zwierząt, izbę spedycji i logistyki, izbę doradców i pośredników ubezpieczeniowych, towarzystwo ekonomiczne, szpital czy izbę inżynierów budownictwa (tabela 1).

Tabela 1. Petycje rozpatrzone przez Komisję do spraw Petycji w trakcie VIII kadencji Sejmu według podmiotu wnoszącego petycję

\begin{tabular}{|l|c|c|}
\hline \multicolumn{1}{|c|}{ Podmiot wnoszący petycję } & Liczba petycji & $\begin{array}{c}\text { Liczba petycji } \\
\text { w } \%\end{array}$ \\
\hline Osoby fizyczne & 485 & 80,2 \\
\hline Stowarzyszenia & 55 & 9,1 \\
\hline Związki (w tym zawodowe) & 17 & 2,8 \\
\hline Fundacje & 13 & 2,1 \\
\hline Partie polityczne & 7 & 1,2 \\
\hline Spółdzielnie mieszkaniowe & 5 & 0,8 \\
\hline Inne & 23 & 3,8 \\
\hline Suma & 605 & 100 \\
\hline
\end{tabular}

Źródło: opracowanie własne na podstawie: www.sejm.gov.pl 9 (dostęp 18 sierpnia 2020 r.).

W trakcie VIII kadencji Sejmu wnioskodawcy składali petycje z różnych dziedzin. Petycje niedające się zakwalifikować do żadnej z poniżej wymienionych kategorii, które jednocześnie pojawiały się jednostkowo (1-2 petycje), zostały wskazane jako „inne”. Niemalże co dziesiąta petycja dotyczyła spraw związanych z ubezpieczeniami społecznymi, 
emeryturami i rentami (8,4\%), a także prawa cywilnego (zmiany w kodeksie cywilnym, kodeksie postępowania cywilnego, odszkodowania) - 8,3\%, co dowodzi ważności tej tematyki oraz wprowadzenia zmian. Drugim najczęściej pojawiającym się w petycjach tematem było prawo karne (kodeks karny, kodeks postępowania karnego, kodeks karny wykonawczy) $-4,6 \%$, sprawy związane z ochroną zdrowia $-4,5 \%$, a także podatki i opłaty $-4,1 \%$. Nie mniej istotne okazały się sprawy dotyczące ochrony przyrody/środowiska $(3,1 \%)$, związane $\mathrm{z}$ transportem drogowym i prawem o ruchu drogowym $(3,3 \%)$ oraz z zakresu sądownictwa, notariatu, czy związane z zawodem kuratora sądowego i radcy prawnego (3,3\%), co przedstawia tabela nr 2 .

Tabela 2. Petycje rozpatrzone przez Komisję do spraw Petycji w trakcie VIII kadencji Sejmu według tematyki petycji

\begin{tabular}{|l|c|}
\hline \multicolumn{1}{|c|}{ Tematyka petycji } & Liczba petycji w \% \\
\hline Emerytury i renty & 8,4 \\
\hline Prawo cywilne & 8,3 \\
\hline Prawo karne & 4,6 \\
\hline Ochrona zdrowia & 4,5 \\
\hline Podatki i opłaty & 4,1 \\
\hline Adwokatura, sądownictwo, notariat, radcy prawni, & \\
kuratorzy sądowi & 3,3 \\
\hline Prawo o ruchu drogowym, transport & 3,3 \\
\hline Ochrona przyrody/środowiska & 3,1 \\
\hline Aktualizacja niektórych ustaw & 2,5 \\
\hline Prawa obywatelskie & 2,3 \\
\hline Prawo oświatowe, szkolnictwo wyższe & 2,3 \\
\hline Prawo administracyjne & 2,3 \\
\hline Prawo pracy & 2,1 \\
\hline Prawo rodzinne i opiekuńcze & 2,1 \\
\hline Gospodarka nieruchomościami & 2,1 \\
\hline Prawo wyborcze & 2,0 \\
\hline Sprawy międzynarodowe & 1,7 \\
\hline Rynek pracy & 1,5 \\
\hline Prawo wykroczeń & 1,5 \\
\hline Świadczenia rodzinne & 1,5 \\
\hline
\end{tabular}




\begin{tabular}{|l|c|}
\hline \multicolumn{1}{|c|}{ Tematyka petycji } & Liczba petycji w \% \\
\hline Prawo zagospodarowania przestrzennego & 1,3 \\
\hline Regulacje dotyczące Sejmu i Senatu & 1,3 \\
\hline Sprawy dotyczące mediów & 1,3 \\
\hline Prawo spółdzielcze & 1,1 \\
\hline Fundacje i stowarzyszenia & 1,1 \\
\hline Samorząd terytorialny & 1,1 \\
\hline Ochrona zwierząt & 1,1 \\
\hline Krajowa Administracja Skarbowa & 1,1 \\
\hline Pomoc społeczna & 1,0 \\
\hline Ustanowienie lub wykreślenie święta & 1,0 \\
\hline Ustawa o Policji & 1,0 \\
\hline Prawo budowlane & $<1,0$ \\
\hline Sprawy związane z cudzoziemcami & $<1,0$ \\
\hline Prawo pocztowe & $<1,0$ \\
\hline Inne & 26,6 \\
\hline
\end{tabular}

Źródło: opracowanie własne na podstawie: www.sejm.gov.pl (dostęp 18 sierpnia 2020 r.).

W latach 2015-2019 Marszałek Sejmu skierował 605 petycji do rozpatrzenia przez Komisję do spraw Petycji, z czego 45 nie zostało rozpatrzonych w związku z upływem kadencji Sejmu. W zdecydowanej większości nie uwzględniono żądania będącego przedmiotem petycji $46,1 \%$, a rozpatrzeniem co trzeciej petycji $(33,4 \%)$ było przygotowanie bądź uchwalenie dezyderatu ${ }^{50}$. Komisja zdecydowała się na przygotowanie lub wniesienie projektu ustawy w przypadku 53 petycji $(8,8 \%)$. Jednak nie zdążyła rozpatrzyć 45 petycji w związku z upływem kadencji Sejmu, natomiast 10 pozostawiła bez rozpatrzenia (w tym 3 petycje $z$ uwagi na brak wskazania miejsca zamieszkania podmiotu wnoszącego petycję, natomiast 8 petycji w związku z art. 12 ustawy o petycjach, a więc petycje w tej samej sprawie były już rozpatrzone przez PET). Poprzez inny

50 Zgodnie z regulaminem Sejmu „Dezyderat zawiera postulaty komisji w określonych sprawach i może być skierowany do Rady Ministrów lub poszczególnych jej członków, Prezesa Najwyższej Izby Kontroli, Prezesa Narodowego Banku Polskiego, Prokuratora Generalnego oraz Głównego Inspektora Pracy”, art. 159 ust. 1 regulaminu Sejmu. 
sposób załatwienia petycji autor rozumie: skierowanie petycji do Komisji Regulaminowej i Spraw Poselskich (1), Komisji Sprawiedliwości i Praw Człowieka (2), częściowo nieuwzględnienie żądania będącego przedmiotem petycji, a w odniesieniu do pozostałych postulatów podjęcie decyzji o przygotowaniu dezyderatów (4), przekazanie petycji do komisji, która zostanie wyznaczona do rozpatrzenia projektu ustawy (2), częściowo podjęcie decyzji o uchwaleniu dezyderatów, a częściowo zwrócenie się do Komisji Samorządu Terytorialnego i Polityki Regionalnej o wyrażenie opinii (2), częściowo nieuwzględnienie żądania, a w odniesieniu do pozostałych postulatów przekazanie petycji Komisji Sprawiedliwości i Praw Człowieka (1), przekazanie petycji Szefowi Krajowego Biura Wyborczego (1), przekazanie petycji do Senatu Rzeczypospolitej Polskiej (1), przedstawienie komisji sejmowej opinii w sprawie rozpatrywanego przez PET projektu ustawy (1) oraz zakończenie pracy nad petycją z uwagi na wniesienie przez Senat projektu ustawy wyczerpującej żądania będące przedmiotem petycji (1), co przedstawia tabela nr 3.

Tabela 3. Sposób rozpatrzenia petycji skierowanych przez Marszałka Sejmu do Komisji do spraw Petycji w trakcie VIII kadencji Sejmu

\begin{tabular}{|l|c|c|}
\hline \multicolumn{1}{|c|}{ Sposób rozpatrzenia petycji } & $\begin{array}{c}\text { Liczba złożo- } \\
\text { nych petycji }\end{array}$ & $\begin{array}{c}\text { Liczba złożo- } \\
\text { nych petycji } \\
\text { w \% }\end{array}$ \\
\hline $\begin{array}{l}\text { Nieuwzględnienie żądania będącego przedmio- } \\
\text { tem petycji }\end{array}$ & 279 & 46,1 \\
\hline Przygotowanie lub uchwalenie dezyderatu & 202 & 33,4 \\
\hline Przygotowanie lub wniesienie projektu ustawy & 53 & 8,8 \\
\hline Pozostawienie petycji bez rozpatrzenia & 10 & 1,7 \\
\hline $\begin{array}{l}\text { Nierozpatrzenie petycji w związku z upływem } \\
\text { kadencji Sejmu }\end{array}$ & 45 & 7,4 \\
\hline Inne & 16 & 2,6 \\
\hline Suma & 605 & 100 \\
\hline
\end{tabular}

Źródło: opracowanie własne na podstawie: www.sejm.gov.pl (dostęp 18 sierpnia 2020 r.).

Najczęstszym sposobem rozpatrzenia petycji przez Komisję do spraw Petycji podczas VIII kadencji Sejmu było nieuwzględnienie żądania będącego przedmiotem petycji (osoby fizyczne, stowarzyszenia, partie 
polityczne, spółdzielnie mieszkaniowe). Jednakże w przypadku fundacji $(38,5 \%)$ i związków $(52,9 \%)$ wniesienie petycji najczęściej kończyło się przygotowaniem lub uchwaleniem przez Komisję dezyderatu. Biorąc pod uwagę skuteczność, aż 20\% petycji złożonych przez spółdzielnie mieszkaniowe zakończyło się przygotowaniem lub wniesieniem projektu ustawy, natomiast w przypadku propozycji osób fizycznych $(8,5 \%)$, a stowarzyszeń - jedynie 5,5\%, co przedstawia tabela nr 4 .

Tabela 4. Sposób rozpatrzenia petycji skierowanych przez Marszałka Sejmu do Komisji do spraw Petycji w trakcie VIII kadencji Sejmu według podmiotu wnoszącego petycję

\begin{tabular}{|l|c|c|c|c|c|c|}
\hline \multirow{2}{*}{$\begin{array}{c}\text { Podmiot } \\
\text { wnoszący } \\
\text { petycję }\end{array}$} & $\begin{array}{c}\text { Nie } \\
\text { uwzględ- } \\
\text { niono } \\
\text { żądania }\end{array}$ & $\begin{array}{c}\text { Przygoto- } \\
\text { wano lub } \\
\text { uchwalono } \\
\text { dezyderat }\end{array}$ & $\begin{array}{c}\text { Przygoto- } \\
\text { wano lub } \\
\text { wniesiono } \\
\text { projekt } \\
\text { ustawy }\end{array}$ & $\begin{array}{c}\text { Pozosta- } \\
\text { wiono } \\
\text { bez roz- } \\
\text { patrzenia }\end{array}$ & $\begin{array}{c}\text { Nie roz- } \\
\text { patrzono }\end{array}$ & Inne \\
\hline OS & 45,8 & 34,8 & 8,5 & 1,6 & 7,0 & 2,3 \\
\hline S & 67,3 & 20 & 5,5 & 1,8 & 1,8 & 3,6 \\
\hline Z & 11,8 & 52,9 & 11,8 & - & 17,6 & 5,9 \\
\hline F & 15,4 & 38,5 & 15,4 & - & 23,0 & 7,7 \\
\hline PP & 57,1 & 28,6 & 14,3 & - & - & - \\
\hline SM & 60,0 & - & 20,0 & - & 20,0 & - \\
\hline Inne & 39,1 & 26,1 & 13,0 & 4,4 & 13,0 & 4,4 \\
\hline
\end{tabular}

Źródło: opracowanie własne na podstawie: www.sejm.gov.pl (dostęp 18 sierpnia 2020 r.). OS - osoby fizyczne; $S$ - stowarzyszenia; $\mathrm{Z}$ - związki (w tym zawodowe); $\mathrm{F}$ - fundacje; PP - partie polityczne; SM - spółdzielnie mieszkaniowe

Analizując czas oczekiwania na rozpatrzenie petycji, odrzucono petycje pozostawione bez rozpatrzenia (10) oraz petycje rozpatrzone w następnej kadencji Sejmu (45). Zatem analizie poddano 550 petycji. Czas oczekiwania liczono, począwszy od dnia złożenia petycji do Sejmu, a skończywszy na dniu posiedzenia Komisji w sprawie rozpatrzenia petycji. Petycja powinna być rozpatrzona bez zbędnej zwłoki, jednak nie później niż w terminie trzech miesięcy od dnia jej złożenia. Najczęściej w tym terminie rozpatrywane były petycje wnoszone przez spółdzielnie 
mieszkaniowe (57,1\%) i związki (47,2\%). Komisja do spraw Petycji w zdecydowanej większości przedłużała jednak termin o kolejne trzy miesiące, zgodnie z ustawą o petycjach. Takie zjawisko zaobserwowano w przypadku petycji składanych przez partie polityczne (75\%), stowarzyszenia (60\%), fundacje $(57,1 \%)$ i osoby fizyczne $(59,1 \%)$. Niespełna $15 \%$ petycji, z uwagi na wystąpienie okoliczności niezależnych od Komisji, rozpatrywano 201 dni lub dłużej (tabela nr 5).

Tabela 5. Czas oczekiwania na rozpatrzenie petycji według podmiotu wnoszącego petycję

\begin{tabular}{|l|c|c|c|}
\hline \multicolumn{1}{|c|}{ Podmiot wnoszący petycję } & $1-100 \mathrm{dni}$ & $101-200 \mathrm{dni}$ & $201 \geq \mathrm{dni}$ \\
\hline Osoby fizyczne & 38,4 & 59,1 & 2,5 \\
\hline Związki (w tym zawodowe) & 47,2 & 50,9 & 1,9 \\
\hline Spółdzielnie mieszkaniowe & 57,1 & 42,9 & - \\
\hline Stowarzyszenia & 40,0 & 60,0 & - \\
\hline Fundacje & 42,9 & 57,1 & - \\
\hline Partie polityczne & 25,0 & 75,0 & - \\
\hline Inne & 36,9 & 52,6 & 10,5 \\
\hline
\end{tabular}

Źródło: opracowanie własne na podstawie: www.sejm.gov.pl (dostęp 18 sierpnia 2020 r.).

Zbadano również zależność pomiędzy czasem oczekiwania na rozpatrzenie petycji a sposobem jej rozpatrzenia. Czas oczekiwania na rozpatrzenie petycji, która zakończyła się przygotowaniem lub wniesieniem projektu ustawy, wynosił najczęściej do 100 dni (50,9\%). Natomiast w przypadku petycji, których żądań nie uwzględniono, było to zazwyczaj 101-200 dni (58,0\%), podobnie w przypadku postanowienia przez Komisję o przygotowaniu lub uchwaleniu dezyderatu (59,0\%), co przedstawia tabela nr 6. 
Tabela 6. Czas oczekiwania na rozpatrzenie petycji według sposobu rozpatrzenia petycji

\begin{tabular}{|l|c|c|c|}
\hline Sposób rozpatrzenia petycji & $1-100 \mathrm{dni}$ & $101-200 \mathrm{dni}$ & $201 \geq \mathrm{dni}$ \\
\hline $\begin{array}{l}\text { Nieuwzględnienie żądania będącego } \\
\text { przedmiotem petycji }\end{array}$ & 38,0 & 58,0 & 4,0 \\
\hline $\begin{array}{l}\text { Przygotowanie lub uchwalenie } \\
\text { dezyderatu }\end{array}$ & 39,0 & 59,0 & 2,0 \\
\hline $\begin{array}{l}\text { Przygotowanie lub wniesienie } \\
\text { projektu ustawy }\end{array}$ & 50,9 & 49,1 & - \\
\hline Inne & 31,3 & 68,7 & - \\
\hline
\end{tabular}

Źródło: opracowanie własne na podstawie: www.sejm.gov.pl (dostęp 18 sierpnia 2020 r.).

\section{ZAKOŃCZENIE}

Prawo petycji uznawane jest za najłatwiejsze, a także najbardziej powszechne i dostępne uprawnienie do dochodzenia przez podmioty przynależnych im praw, wolności oraz ochrony interesów. Jest to jedno z najstarszych praw przynależnych jednostce w państwie demokratycznym. Obecnie obowiązująca ustawa o petycjach ma pewne mankamenty, między innymi brak uregulowania możliwości cofnięcia petycji czy postępowania w sytuacji, gdy petycja zostanie potraktowana jako inne pismo, na przykład skarga lub wniosek. Celem artykułu jest jednak analiza praktyki rozpatrywania petycji przez PET VIII kadencji Sejmu, a nie samej ustawy.

Spośród 605 petycji wniesionych w trakcie trwania VIII kadencji Sejmu aż 80,2\% wnioskodawców stanowiły osoby fizyczne, co dowodzi słuszności wprowadzenia tego rozwiązania do polskiego porządku prawnego - jako narzędzia głównie dla obywateli. Niemalże co dziesiąta petycja dotyczyła spraw związanych z ubezpieczeniami społecznymi, emeryturami i rentami $(8,4 \%)$, a także prawa cywilnego (zmiany w kodeksie cywilnym, kodeksie postępowania cywilnego, odszkodowania) - 8,3\%, co dowodzi o ważności tej tematyki oraz potrzebie wprowadzenia zmian w ocenie licznych podmiotów wnoszących petycje w tych sprawach. Komisja w zdecydowanej większości nie uwzględniła żądania będącego przedmiotem petycji - $46,1 \%$, a rozpatrzeniem co trzeciej petycji $(33,4 \%)$ było przygotowanie bądź uchwalenie dezyderatu. Komisja 
zdecydowała się na przygotowanie lub wniesienie projektu ustawy w przypadku 53 petycji (8,8\%). W terminie trzech miesięcy najczęściej rozpatrywane były petycje wnoszone przez spółdzielnie mieszkaniowe $(57,1 \%)$ i związki (47,2\%). Komisja do spraw Petycji w zdecydowanej większości przedłużała jednak termin o kolejne trzy miesiące, zgodnie z ustawą o petycjach. Takie zjawisko zaobserwowano w przypadku petycji składanych przez partie polityczne (75\%), stowarzyszenia (60\%), fundacje $(57,1 \%)$ i osoby fizyczne $(59,1 \%)$. Czas oczekiwania na rozpatrzenie petycji, która zakończyła się przygotowaniem lub wniesieniem projektu ustawy, wynosił najczęściej do 100 dni (50,9\%). Natomiast w przypadku petycji, których żądań nie uwzględniono, było to zazwyczaj 101-200 dni (58,0\%), podobnie w przypadku postanowienia przez Komisję o przygotowaniu lub uchwaleniu dezyderatu (59,0\%).

Podsumowując, warto wskazać na szybki okres rozpatrywania petycji (w porównaniu np. z obywatelską inicjatywą ustawodawczą) oraz stosunkowo prostą dla wnioskodawcy formę. Jest to zatem narzędzie dostępne dla przeciętnego obywatela, ponadto otrzymuje on informację o sposobie rozpatrzenia petycji, a w przypadku niekorzystnego rozwiązania może sporządzić nową petycję. Nie ma również ograniczenia w stosunku do liczby spraw, które można zamieścić w jednej petycji. Poza osobami fizycznymi z uprawnienia tego korzystali także inni wnioskodawcy (np. osoby prawne). Jednak okres jednej kadencji Sejmu nie daje jednoznacznej odpowiedzi, czy obywatele w przyszłości będą korzystać z tego rozwiązania częściej, a także jaka będzie jego skuteczność.

\section{PRAWO PETYCJI W TEORII I PRAKTYCE SEJMU VIII KADENCJI}

\section{Streszczenie}

Prawo petycji zostało wprowadzone do polskiego porządku prawnego w Konstytucji marcowej z 1921 r. W kolejnych ustawach zasadniczych przepis ten został wykreślony i pojawił się ponownie w Konstytucji Rzeczypospolitej Polskiej z 1997 r. Przez wiele lat prawo petycji było nieprecyzyjnie określone (mylone często ze skargami i wnioskami). W artykule dokonano analizy petycji wnoszonych w trakcie VIII kadencji 
Sejmu, ponieważ była pierwszą, w której obywatele mogli w pełni realizować swoje uprawnienie, zgodnie z ustawą o petycjach uchwaloną 11 lipca 2014 r. Analizie poddano 605 petycji, biorąc pod uwagę kryterium sposobu załatwienia sprawy, tematykę (przedmiot) wniesionych do Sejmu petycji czy czas oczekiwania na rozpatrzenie petycji. Okres jednej kadencji Sejmu nie daje jednoznacznej odpowiedzi, czy obywatele w przyszłości będą korzystać z tego rozwiązania częściej oraz jaka będzie jego skuteczność. Obecna kadencja Sejmu niedawno się rozpoczęła, zatem większe możliwości porównania pojawią się nie szybciej niż w połowie jej trwania. W artykule, $\mathrm{z}$ uwagi na jego ramy, podjęto jedynie najważniejsze kwestie związane z interpretacją ustawy o petycjach oraz praktyką rozpatrywania petycji przez Sejm VIII kadencji.

\section{Theory and Practice of the Polish Law on Petitions during the Eighth Term of Sejm}

\section{Summary}

The right to petition was introduced in the Polish legal order in the March Constitution of 1921. The provision was omitted in later constitutions and only reappeared in the 1997 Constitution. For many years, the right to petition was imprecise and often confused with complaints and requests. This article examines the petitions submitted during the 8th term of Sejm (2015-2019), which was the first in which citizens could exercise their full right, pursuant to the act on petitions adopted on 11 July 2014. I looked at 605 petitions, taking into account the criteria of how the matter was settled, the subject of the petition, and the time that passed before Sejm considered it. A single (four-year) term of Sejm is not enough to give a definitive answer to how often Polish citizens will be likely to resort to this measure in the future, and what its effectiveness will be. The current term of Sejm started in 2019, so the opportunity for a comparison will not arise until about midterm (i.e. around 2022). The limited size of my article has forced me to address only the most important issues involved in the interpretation of the Polish act on petitions and the way the 2015-2019 Sejm handled citizens' petitions. 
Słowa kluczowe: petycja; obywatele; Sejm VIII kadencji; demokracja. Keywords: petition; citizens; the 2015-2019 Sejm; democracy.

\section{Literatura}

Banaszak B., Konstytucja Rzeczypospolitej Polskiej. Komentarz, Warszawa 2009, s. 323.

DziaŁocha K., Prawo petycji w obowiązujacym ustawodawstwie i proponowane kierunki zmian, [w:] Prawo petycji w ustawodawstwie polskim, red. J. TrACZ-Dral, Warszawa 2008, s. 1-8.

Grabarczyк K., Prawo petycji w Rzeczypospolitej Polskiej oraz w Republice Litewskiej, «Kortowski Przegląd Prawniczy» 1/2016, s. 32-38.

Grabowska S., Kapusta P., Pojęcie i charakter prawa petycji, [w:] Teoretyczne i praktyczne aspekty realizacji prawa petycji, red. R. BALICKI, M. JABŁoŃsKI, Wrocław 2015, s. 37-45.

Gromeк Z., Realizacja prawa petycji przez Sejm VIII kadencji (lata 2015-2018). Wybrane zagadnienia, «Przegląd Sejmowy» 3.152/2019, s. 21-40.

Masternak-Kubiak M., Kuczma P., Prawo petycji jako publiczne prawo podmiotowe (aspekt podmiotowy i przedmiotowy), [w:] Teoretyczne i praktyczne aspekty realizacji prawa petycji, red. R. BALICKI, M. JABŁOŃsKI, Wrocław 2015, s. 259-281.

Or£owski W., Konstytucyjne uwarunkowania prawa petycji, [w:] Prawo petycji w ustawodawstwie polskim, red. J. Tracz-Dral, Warszawa 2008, s. 9-22.

Piotrowski R., Konstytucyjne uwarunkowania prawa petycji oraz pożądanych kierunków zmian legislacyjnych $w$ tym zakresie, [w:] Prawo petycji w ustawodawstwie polskim, red. J. Tracz-DraL, Warszawa 2008, s. 23-31.

Rytel-WARzocha A., Instytucja petycji w Polsce oraz w krajach europejskich - stan obecny i perspektywy, [w:] Instytucja petycji w Polsce oraz w innych krajach europejskich - stan obecny i perspektywy, red. R. STAWICKI, Warszawa 2015, s. 3-41.

Sokolewicz W., Uwagi do art. 63, [w:] Konstytucja Rzeczypospolitej Polskiej. Komentarz, red. L. GarLICKI, Warszawa 2005, s. 1-11.

WójCicкA E., Przywrócenie instytucji petycji w polskim porządku prawnym, «Ruch Prawniczy, Ekonomiczny i Socjologiczny» 4/2006, s. 31-44.

Wójcicka E., Ustawa z dnia 11 lipca 2014 r. o petycjach - uwagi krytyczne, «Ruch Prawniczy, Ekonomiczny i Socjologiczny» 1/2017, s. 159-172.

Zį̨ва-ZaŁucka H., Prawo petycji w Rzeczypospolitej Polskiej, «Przegląd Prawa Konstytucyjnego» 4/2010, s. 9-22. 